\title{
A Preliminary Study on The Determination of Reproductive Biology of European Pilchard, Sardina pilchardus (Walbaum, 1792) Distributed in The Aegean Sea
}

\author{
Burcu Taylan ${ }^{1, a, *}$, Ertan Taskavak ${ }^{1, b}$, Sule Gurkan ${ }^{1, c}$ \\ ${ }^{I}$ Department of Hydrobiology, Faculty of Fisheries, Ege University, 35040 Bornova/Izmir, Turkey \\ *Corresponding author

\begin{tabular}{l|l}
\hline A R T I C L E I N F O & A B S T R A C T \\
\hline & Sardina pilchardus is a multiple spawning fish, i.e., the species that spawns periodically during the
\end{tabular} \\ Research Article \\ spawning period. In order to examine the reproduction biology of the species, the specimens were \\ obtained in the known spawning period indicated by the current literature obtained from fishers who \\ were commercially fishing in December 2018 and January-February 2019. After the fork length and \\ Received : 14/10/2019 \\ Accepted : 14/11/2019 \\ total length together with their weight measurements, the specimens were dissected in the laboratory. \\ The adult females' gonads were then fixed in $4 \%$ formalin solution for fecundity. A total of 170 \\ individuals was examined and the values of their fork length, total length and weight were computed \\ as 9.7-13.4 cm (mean: 11.16 \pm 0.81 ), 10.5-15 cm (mean: 12.3 \pm 0.89$), 8.06-23.7 \mathrm{~g}$ (mean: 12.7 \pm 2.93 ), \\ respectively. 44 of the supplied specimens were male $(25.9 \%), 122$ female $(71.8 \%)$ and $4(2.3 \%)$ \\ Keywords: \\ European pilchard \\ Sardina pilchardus \\ Reproduction \\ Fecundity \\ uncertain, thus, the female: male ratio was determined as $2.77: 1$. According to $\chi^{2}$ test results, a \\ statistically significant difference was observed among individuals. For the specimens examined, the \\ fork length-weight relationship was calculated as $\mathrm{W}=0.0098 \mathrm{FL}^{2.96}$, while total length-weight \\ relationship was $\mathrm{W}=0.0071 \mathrm{TL}^{2.97}$. In order to calculate the fecundity, sub-samples were taken from \\ the anterior, median and posterior parts of 15 ovaries in the ration of $2-5 \%$ of the ovary weight and \\ the mature oocytes were counted. As a result, the species' fecundity was found to be between 4,600 - \\ $9,800(6,110 \pm 1,755)$. The relationship between total length and fecundity was computed as $\mathrm{W}=$ \\ 1,640.7 TL-13,907 and a linear relationship was determined. \\ Aegean Sea
}

b@ertan.taskavak@ege.edu.tr (iD https://orcid.org/0000-0001-8949-1827 . 
In the laboratory, for fork and total lengths of the specimens millimetric measurement board $(\mathrm{cm})$ was used and they were weighted with $0.01 \mathrm{~g}$ precision balance. The specimens were dissected for sex determination. Total length-weight relationship the formula given by Ricker (1975) was used. The gonads of adult females were fixed in $4 \%$ formalin solution to determine fecundity. Holden and Raitt (1974) was used to determine the maturity stages of ovaries (Table 1).
In order to determine the fecundity, sub-samples at a rate of $2-5 \%$ of whole ovary weight were taken from the anterior, median and posterior parts of mature ovaries and thus the total ovary weight was tried to calculate by counting the mature oocytes. The determination of fecundite was made according the method given by Hunter et al., (1985). $\chi^{2}$ (chi-square) test was used to determine whether there was a statistically significant difference between sexes (Sumbuloglu and Sumbuloglu, 1993).

Table 1 A five-point maturity scale for partial spawners*

\begin{tabular}{l|ll}
\hline Stage & State & Description \\
\hline I & Immature & $\begin{array}{l}\text { Ovary and testis about 1/3rd length of body cavity. Ovaries pinkish, translucent; } \\
\text { testis whitish. Ova not visible to naked eye. }\end{array}$ \\
\hline II & $\begin{array}{l}\text { Maturing virgin and } \\
\text { recovering spent }\end{array}$ & $\begin{array}{l}\text { Ovary and testis about } 1 / 2 \text { length of body cavity. Ovary pinkish, translucent; } \\
\text { testis whitish, more or less symmetrical. Ova not visible to naked eye. }\end{array}$ \\
\hline III & Ripening & $\begin{array}{l}\text { Ovary and testis is about 2/3rds length of body cavity. Ovary pinkish-yellow } \\
\text { colour with granular appearance, testis whitish to creamy. No trans- parent or } \\
\text { translucent ova visible. }\end{array}$ \\
\hline IV & Ripe & $\begin{array}{l}\text { Ovary and testis from 2/3rds to full length of body cavity. Ovary orange-pink in } \\
\text { colour with conspicuous superficial blood vessels. Large transparent, ripe ova } \\
\text { visible. Testis whitish- creamy, soft. }\end{array}$ \\
\hline V & Spent & $\begin{array}{l}\text { Ovary and testis shrunken to about 1/2 length of body cavity. Walls loose. Ovary } \\
\text { may contain remnants of disintegrating opaque and ripe ova, darkened or } \\
\text { translucent. Testis bloodshot and flabby. }\end{array}$ \\
\hline
\end{tabular}

*Holden and Raitt (1974)

\section{Results}

A total of 170 specimens were examined and 44 of them were male (25.9\%), 122 female (71.8\%) and 4 uncertain $(2.3 \%)$. The female:male ratio was 2.77:1.00. According to the $\chi^{2}$ test result $\left(\chi^{2}=16.11>\chi_{\text {t0.05 }}^{2}=3.85\right.$, $\mathrm{P}>0.05)$, a statistically significant difference was observed among the specimens. Fork length-weight relationship and total length-weight relationship were computed as $\mathrm{W}=0.0098 \mathrm{FL}^{2.96}\left(\mathrm{R}^{2}=0.92\right)$ and $\mathrm{W}=0.0071 \mathrm{TL}^{2.97}$ $\left(\mathrm{R}^{2}=0.92\right)$, respectively (Figure 1 and 2$)$.

For fecundity determination, mature oocytes in subsamples (at a rate of 2-5\% of whole ovary weight) that were taken from the anterior, median and posterior parts of 15 ovaries were counted. Consequently, the fecundity of the species was determined between 4,600-9,800 (6,110 \pm 1,755). The total length-fecundity relationship was computed as $\mathrm{W}=1,640.7 \mathrm{TL}-13,907\left(\mathrm{R}^{2}=0.81\right)$ and a linear relationship was determined (Figure 3 ).

\section{Discussion}

We here conducted a preliminary study to determine the reproductive biology of The European pilchard, Sardina pilchardus (Walbaum, 1792), collected from the Aegean Sea. In their study on sardines captured from Croatia, Mustać and Sinovčič (2010) gave total length and weight values of the specimens as $13.0-19.0 \mathrm{~cm}$ and $16.72-51.45$, respectively, and determined male:female ratio as 1.0:1.2. The total length-weight relationship given by them was $\mathrm{W}=0.026 \mathrm{LT}^{2.5538}$ (Mustać and Sinovčič, 2010). In our study, length and weight values were $10.50-15.00 \mathrm{~cm}$ and 8.06 $23.70 \mathrm{~g}$ and it was found that the specimens we evaluated in this study were smaller than those evaluated by Mustać and Sinovčič (2010). While total length-weight relationship was $\mathrm{W}=0.0071 \mathrm{TL}^{2.97}$ and female: male ratio was $2.77: 1.00$ in our study, it was found that the females were outnumbered.

In their study on specimens from Boka Kotorska Gulf, while Peš́ić et al. (2010) gave the total length and weight values $8.7-14.7 \mathrm{~cm}$ and $4.67-22.61 \mathrm{~g}$, they calculated while the total length-weight relationship as $\mathrm{W}=0.0059 \mathrm{LT}{ }^{3.0891}$ and female: male ratio as 1.49: 1.00, respectively. Length and weight values of the specimens they examined were similar to those in our study and likewise, it was found that females were outnumbered as in our study. Differences between length and weight values determined among studies are caused by sampling area and time, number of specimens, sampling number, type of fishing, sexes and annual changes of species feeding, gonad maturity and environmental conditions (Bagenal and Tesch, 1978; Froese, 2006).

In his study of the reproductive biology of sardines from Edremit Bay, Izmir Bay and Büyük Menderes Delta, Cihangir (1990) computed the female: male ratio as 1.00: 0.28, 1.00: 0.83 and 1.00: 0.82, respectively, and found that females are outnumbered as in our study. Cihangir (1990) found that fecundity was 2000-3000 among the specimens with a length of $12-13 \mathrm{~cm}$, and 10000-15000 among the specimens with 16-17 cm lengt. In our study, we had the specimens between the lengths of $10.5-15.0 \mathrm{~cm}$, fecundity was computed as 4600-9800. Consequently, we thought that the fecundity values calculated between the similar size groups of both studies were almost similar.

As indicated above, in this preliminary study the reproductive biology of an economic fish species, which is very important in Turkish fisheries, was examined. The results obtained here show that the reproduction biology of the species should be examined in more detail by a whole year sampling. In this way, more detailed information may be obtained about the control and continuity of the sardine stocks and sustainable sardine fishing. 


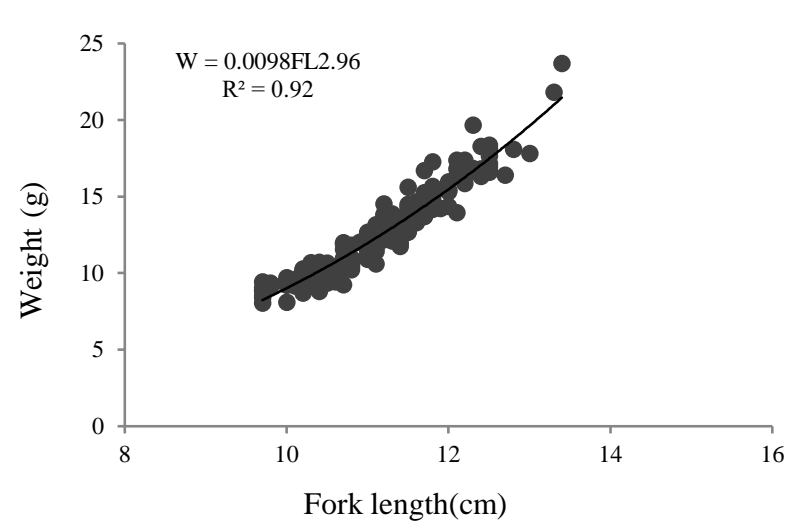

Figure 1 Fork length-weight relationship of 170 Sardina pichardus specimens examined.

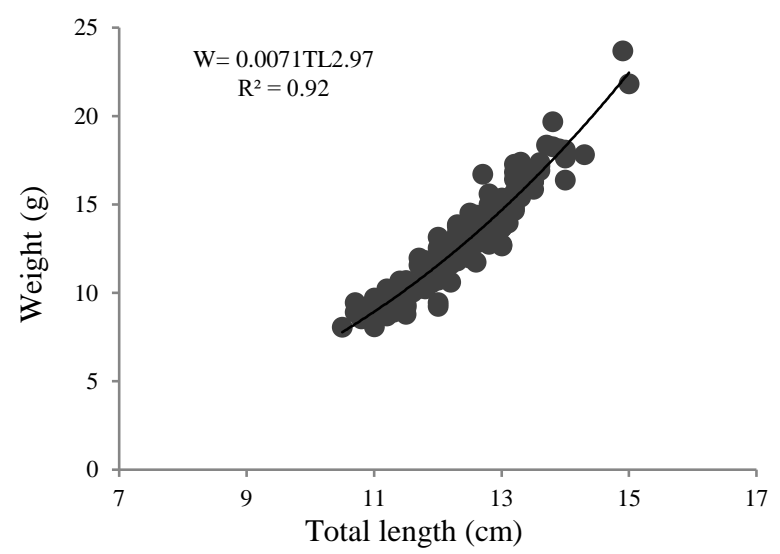

Figure 2 Total length-weight relationship of 170 Sardina pichardus specimens examined.

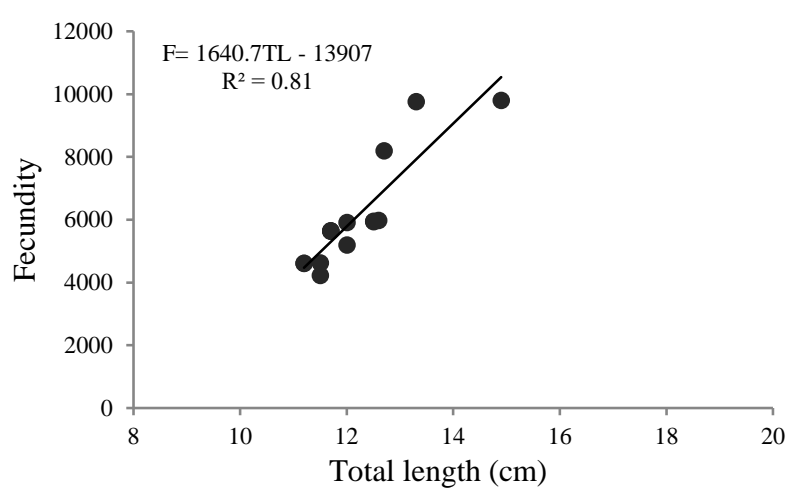

Figure 3 The total length-fecundity relationship

\section{References}

Abderrazik W, Baali A, Schahrakane Y, Tazi O. 2016. Study of reproduction of sardine, Sardina pilchardus in the North of Atlantic Moroccan area, AACL Bioflux, 9: 3.

Artüz MI. 1960. Some observations on the fluctiations in the catch of Sardina pilchardus in Turkish waters. GFCM.FAO Fish. Rep., 3:1033-1042.

Bagenal TB, Tesch FW. 1978. Age and growth. In: Methods for assessment of fish production in fresh waters. Bagenal (Ed.), IBP Handbook No.3, 3rd ed. Blacwell Science Publishers pp. 101-136.

Cihangir B. 1993. Ege Denizi'nde Sardalya Balı̆̆1, Sardina pilchardus (Walbaum, 1792)'un Üremesi. TUBITAK, 33-50.

Cihangir B, Tıraşın EM. 1990. Ege Denizi sardalyası (Sardina pilchardus Walb 1792)'nın gonadasomatik indeksi ve kondisyon faktörü üzerine araştırmalar. X Ulusal Biyoloji Kongresi, 4:233-242.
Demir N, Demir M. 1961. Note on te sardine (Clupea pilchardus Walb.) and its resproduction in the sea of Marmara. GFCM. FAO Fish. Rep., 6:221-225.

Ferreiro MJ, Labartau U. 1984. Spawning areas and seasons of three Clupeid species (Sardina pilchardus, Sprattus sprattus and Engraulis encrasicolus) in the Rio of Vigo (Galician Coasts. NW Spain). Cybium, 8(3):79-96.

Froese R. 2006. J. appl. Ichthyol., 22: 241-253.

Holden MJ, Raitt DFS. 1974. Manual of fisheries science. Part 2Methods of resource investigation and their application. Rome: Food and Agriculture Organization of the United Nations.

Hunter JR, Macewicz BJ. 1985. Measurement of spawning frequency in multiple spawning fishes. In: An Egg Production Method for Estimating Spawning Biomass of Pelagic Fish: Application to the Northern Anchovy, Engraulis mordax (ed. R. Lasker ), NOAA Technical Report NMFS, US Department of Commerce, Springfield, VA, USA, 79-93 p. pp.

Kemahlı S. 1984. Urla Limanı ve civarında yaşayan sardalya balıklarının (Sardina pilchardus Walb., 1792) biyolojisi ve popülasyon dinamiği üzerine araştırmalar. DEÜ.DBTE Yüksek Lisans Tezi.

Mustać B, Sinovčić G. 2008. Reproduction, length-weight relationship and condition of sardine, Sardina pilchardus (Walbaum, 1792), in the eastern Middle Adriatic Sea (Croatia). Periodicum Biologorum, 112(2):133-138.

Nejedli S, Petrinec Z, Etrinec SK, Srebočan E. 2004. Annual oscillation of ovarian morphology in European pilchard (Sardina pilchardus Walbaum) in the northern Adriatic Sea. Veterinarski Arhiv, 74(2): 97-106.

Özelsel S. 1982. Methods of age determination in Sardina pilchardus (Walbaum) and Dicentrarchus labrax (L.) European Facts of Science Journal, 1:57-66.

Peš̉ić A, Durović M, Joksimović A, Regner S, Simonović P, Glamuzina P. 2010. Some reproductive patterns of the sardine, Sardina pilchardus (Walb, 1792), in Boka Kotorska Bay (Montenegro, southern Adriatic Sea), Acta Adriatrica, 51(2):159-168.

Ricker WE. 1975. Computation and interpretation of biological statistics of fish populations. Bull. Fish. Res. Board Can. 191, 382 p. DOI / ISBN.

Rodrigez JM, Rubin JP. 1990. Ichthyoplankton community in the Southern Coast of Galicia (NW of Spain) during April 1987, with special reference to sardina (Sardina pilchardus Walb.) eggs and larvae. ICES C.M.1990/L: 16, Ref. H. 9 pp.

Sinovcic G. 1983. The fecundity-aga relationship of the sardine. Sardina pilchardus (Walb.) in the Central Adriatic. Rapp. Comm. İnt.Mer Medit, 28(5):31-32.

Southward AJ, Demir N. 1974. Seasonal changes in dimensions and viability of the developing eggs of the Comish pilchard (Sardina pilchardus Walb.) off Plymouth. İn Blaxter, J.H.S. (editor) The Early life History of Fish. Spinger-Verlag. Berlin: 53-68.

Sumbuloglu K, Sumbuloglu V. 1993. Biostatistics. 4. Issue. 269. Ankara, Turkey.

Tsikliras A, Koutrakis ET. 2013. Growth and reproduction of European sardine, Sardina pilchardus (Pisces: Clupeidae), in northeastern Mediterranean. Cahiers de Biologie Marine, 54: 365-374.

Torcu H. 1987. İzmir Körfezi'nde sardalya (Sardina pichardus Walb.1792) popülasyonu üzerine biyolojik ve ekolojik bir araştırma. DEÜ.DBTE Yüksek Lisans Tezi.

TUIK. 2017. Turkish Statistical Institute.

Whitehead PJP. 1985. FAO Species Catalogue. Vol. 7. Clupeoid fishes of the world (suborder Clupeoidei). An annotated and illustrated catalogue of the herrings, sardines, pilchards, sprats, shads, anchovies and wolf-herrings. FAO Fish. Synop., 125(7/1):1-303. Rome: FAO.

Yannopoulos C. 1977. The reproduction and the egg size variations of Sardina pilchardus Walb. In the Thermaikos Gulf. Aegean Sea. Rapp. Comm. İnt. Mer Medit., 24, 5:73-75. 